International Journal of Social Science and Economic Research

ISSN: 2455-8834

Volume:05, Issue:10 "October 2020"

\title{
SOLAR ENERGY FOR ATMANIRBHARTA IN INDIA'S AGRICULTURE SECTOR
}

\author{
Adiel R. Kynta \\ PhD Candidate in Political Geography \\ Centre for International Politics, Organization and Disarmament, School of International Studies, \\ Jawaharlal Nehru University, New Delhi.
}

DOI: 10.46609/IJSSER.2020.v05i10.010 URL: https://doi.org/10.46609/IJSSER.2020.v05i10.010

\begin{abstract}
India is predominantly an agrarian economy that has traditionally relied on the monsoon. However, its contribution to the country's Gross Value Added (GVA) is less than one-fifth in comparison to the manufacturing and service sector. The ailing sector has been receiving a multitude of sops from the Central and state governments for improvement in the socioeconomic and environmental conditions of the rural and agricultural areas. However, the outputs have not been impressive, except for the increase in food production. Socio-environmental impacts in the rural and agricultural scenario tell a different story. For instance, growing regional disparities in production, increasing farmer suicides, depleting ground water, rising soil toxicity have risen dramatically in the recent past etc. Furthermore, the impacts of climate change have become more evident in agriculture. This highly vulnerable sector needs robust and high-risk management solutions. This article attempts to direct the reader's attention to the significant role that solar energy technologies can have in not only mitigating climate risks but also improve rural and agricultural livelihoods and make the sector resilient and self-reliant in the years to come.
\end{abstract}

Key words: Atmanirbharta., Agriculture, Solar energy, Solar technologies, Climate change,

\section{INTRODUCTION}

Agriculture and allied activities are vital for a country like India as it accounts for the primary source of livelihood of about 58 per cent of India's population. Its contribution to Gross Value Added of India in 2018-19 was 15.87\% (Central Statistics Office, Ministry of Statistics and Programme Implementation); it more than 50\% in 1950-51 (Central Statistical Organisation). After more than 70 years of independence, the sector lags behind tremendously, as the state has not devised as many desired mechanisms to withstand economic, environmental, social, political shocks, in comparison to other sectors of the economy. The impacts of climate change are 


\section{International Journal of Social Science and Economic Research}

ISSN: $2455-8834$

Volume:05, Issue:10 "October 2020"

becoming more visible - over the decades - in the form of increasing intensity, frequency, duration and paradoxes of torrential rainfall, cyclones, floods, droughts and forest fires experienced simultaneously over the geographical territory of the country. This implies that agriculture will become more susceptible to climate-related problems in the future. Indian farmers have traditionally relied on the gamble of the monsoon, but the odds of surviving this gamble are almost zero without adapting and adopting measures to mitigate the impacts of climate change and become more resilient and self-reliant in the future.

The policies of the agriculture and allied sectors must keep up with the changing times to enable them to contribute more to the economy and help enhance livelihoods. Reorienting the agriculture sector in terms of technology-use, financial and social support, is the need of the hour, keeping sustainable use of natural resources in mind to create responsible consumption and production as an SDG $12{ }^{1}$ target that India plans to achieve by 2030.

Solar is not a conventional source of energy. However, with growing consciousness about the impacts of climate change, and the energy sector being one of the main culprits for greenhouse gas (GHG) emissions globally, a transition towards renewable energy for electricity has been seen as a solution for access and use of clean energy (SDG 7) in the long term. In the Conference of Parties of the United Nations Framework on the Convention of Climate Change, conducted in Paris in 2015 (COP 15), India and France pioneered the creation of the International Solar Alliance (ISA) -the only multinational organisation in the world to focus solely on solar energy for a sustainable future.It is the only UN body to be headquartered in India. This puts India in a position to use its solar potential to call itself a global leader in renewables, specifically solar energy.

The government intends to invest in the agriculture infrastructure of the country as it aims to double farmers' income by 2022. And improve the agriculture sector. The article attempts to direct the reader's attention to the areas where solar energy can help transform the rural and agricultural population in becoming Atmanirbhar (self-reliant) than ever before. It seeks to present the vast potential and perspectives for solar energy in the rural and agriculture sector to make it easier in risk management, enhance socio-economic conditions of the population and ultimately self-resilient

\section{SCENARIO OF SOLAR ENERGY IN INDIA}

India's solar story has attracted many studies worldwide as it is one of the fastest growing sector in terms of power generation along with China. The Solar energy sector in India emerged after

\footnotetext{
${ }^{1}$ SDG 12 Sustainable Development Goal 12 aims at ensure sustainable Consumption and Production. By 2030, the target is to halve per capita global food waste at the retail and consumer levels and reduce food losses along production and supply chains, including post-harvest losses.
} 
the National Action Plan on Climate Change (NAPCC) dedicated one specific mission on a developing solar energy as a measure to combat climate change. The Jawaharlal Nehru National Solar Mission (JNNSM) was the first 'mission' to be created and operationalised in 2010 with an aim to establish India as a global leader in solar energy. It aimed to generate 100GW (60 GW of grid connected, ground mounted plants and $40 \mathrm{GW}$ of solar rooftop plants) of solar energy by 2022 to combat climate change. Table 1furnishes the proposed roadmap of JNNSM in 3 phases.

Table1. Proposed Roadmap of JNNSM

\begin{tabular}{|c|c|c|c|c|}
\hline \multirow[t]{2}{*}{ Period } & \multicolumn{3}{|c|}{ Application Segment } & \multirow[t]{2}{*}{ Focus Area } \\
\hline & $\begin{array}{l}\text { Solar } \\
\text { Collectors }\end{array}$ & $\begin{array}{l}\text { Off-grid } \\
\text { solar } \\
\text { applications } \\
\text { (MW) }\end{array}$ & $\begin{array}{l}\text { Utility grid } \\
\text { power (with } \\
\text { rooftops) }\end{array}$ & \\
\hline $\begin{array}{l}\text { Phase 1 } \\
(2010-13)\end{array}$ & 7 & 200 & $1,000-2,000$ & $\begin{array}{l}\text { Solar Thermal and off- } \\
\text { grid systems to serve } \\
\text { population without } \\
\text { access to power; } \\
\text { modest capacity addition } \\
\text { in the grid system }\end{array}$ \\
\hline $\begin{array}{l}\text { Phase } 2 \\
(2013-17)\end{array}$ & 15 & 1000 & $\begin{array}{l}4000- \\
10,000\end{array}$ & $\begin{array}{l}\text { Ramp up capacity to } \\
\text { create conditions for } \\
\text { scaled up \& competitive } \\
\text { solar energy in India }\end{array}$ \\
\hline $\begin{array}{l}\text { Phase } 3 \\
(2017-22)\end{array}$ & 20 & 2000 & 2000 & $\begin{array}{l}\text { Create conditions for } \\
\text { solar manufacturing } \\
\text { capabilities, especially } \\
\text { for solar thermal for } \\
\text { indigenous production; } \\
\text { global rarket } \\
\text { leadership. }\end{array}$ \\
\hline
\end{tabular}

Source: https://www.seci.co.in/upload/static/files/mission_document_JNNSM(1).pdf

The Solar Energy Corporation of India (SECI) under the Ministry of New and Renewable Energy (MNRE) was established in 2011 to facilitate the implementation of programmes under the JNNSM. However, with the rapid growth of renewables in India, SECI now facilitates all renewable energy sources. 


\section{International Journal of Social Science and Economic Research}

ISSN: $2455-8834$

Volume:05, Issue:10 "October 2020"

According to the MNRE (2019), India has the world's largest renewable expansion programme and currently ranks 5th in global installed renewable energy (RE) capacity. Solar energy generation has increased rapidly in a decade from an installed capacity of $10 \mathrm{MW}$ in 2010 to 36 GW. It contributed about $36 \mathrm{GW}$ out of $372.6 \mathrm{GW}$ of total installed capacity of utilitiesin India (Central Electricity Authority 31. 08.2020). The government, in the recent past, has focussed on the promotion of renewable with a myriad of policies and initiatives in all the sectors of the economy, with special focus on research, development and deployment( RD\&D). The targets under different phases of the JNNSM have not been met as desired but the race to achieve them is still on.

The MNRE is aware of the potential that the agriculture sector has with respect to the adoption and growth of solar energy technologies. For the large scale penetration and use of solar technologies, the government has created various schemes like the Scheme for Development of Solar Parks and Ultra Mega Solar Power Projects; PM-KUSUM(Pradhan Mantri Kisan Urja Suraksha evam Utthaan Mahabhiyaan), RooftopPV (Photovoltaic) and Small Solar Power Generation Programme; distribution of solar lamps and lanterns; lighting of houses under off-grid and decentralised Solar Programme; Atal Jyoti Yojana for Solar Street Lights; and, solar PV power plants on Canal Banks. Waiver for Inter-State Transmission charges for solar and wind, are some of the other popular schemes.

The promotion of schemes like Pradhan Mantri Fasal Bima Yojana, Pradhan Mantri Krishi Sinchayee Yojana (PMKSY)via Agricultural Technology Management Agency (ATMA) at the district level for disbursal of grants, e- NAM( e- National Agriculture Market), e-Pashuhaat ( web portal for increasing productivity in the livestock sector), seed centres, information centres , Kirishi Vigyan Kendras (KVK), and kiosks for weather updates require the farmers to have ICTs or Information Communication technologies to extend the knowledge of latest innovations in RD\&D for information dissemination. This has helped them improve the production of food grains and incomes but some villages that are in remote and inaccessible areas do not have these facilities due to lack of power supply. While some schemes have been discontinued due to various reasons. PM-KUMSUM which was started in 2019 with much fan-fare has been implemented across the country and seems to be one of the most popular schemes related to the adoption of solar technologies for transforming rural and agricultural life and improve climate resilience and sustainable development.

\section{Agriculture in India}

The production of food grains has increased manifold over the decades but the growth of the sector has stagnated (T. Krishnakumar 2019). Its contribution to the GVA has fallen in comparison to other sectors of the economy. Agriculture has been rife with poor infrastructure 


\section{International Journal of Social Science and Economic Research}

ISSN: $2455-8834$

Volume:05, Issue:10 "October 2020"

facilities, both physical and social; there is an absence of coordination in implementation of various programmes and schemes. The high degree of uncertainty that is linked to employment and income in the agriculture sector makes it undesirable for many to adopt it as a means of livelihood and the high rate of migration of population from rural to urban areas is a case in point.

As per the Annual Report of the Ministry of Agriculture and Farmers Welfare (2019), 140.1 million hectares accounted for net cropped area out of the total 328.7 million hectares of geographical area of the country. This indicates that more than a third of the land is used for agricultural and allied purpose. The net irrigated area in the country is about 68.4 million hectares. Tube wells and canals have been the major source of irrigation for a large part of India's area under agriculture (Ministry of Agriculture and Farmers Welfare 2019). Farmers in most irrigated areas have traditionally relied on diesel or electricity supply from utilities that the government provides at a subsidy. The unscientific and unregulated manner of power and water consumption over the years has led to an unsustainable fall in water tables in many parts of the country and rise in levels of pollution of water, soil and air.

\subsection{What ails India's Agricultural sector?}

The Indian farmer was at the forefront in the fight for independence but is now and dependent on the monsoon for a livelihood, and also most vulnerable to ecological, economic and social disruptions and shocks. Innovations in agriculture have trickled down very slowly and sparsely. The contribution of agriculture to the GVA is the biggest evidence of this slow growth. The following are a few reasons for the ailing condition of agriculture in India:

- More than 85 percent of India's farmers are marginal and small farmers with fragmented or no land holdings at all (Ministry of Agriculture). Cultivation of crops in small land holdings have been part of the tradition of agriculture in India. The small holdings make it difficult for implementation of many government policies.

- With Faster urbanization and industrialization, lands, which were earlier under agriculture and forests, are now being used for residential or industrial purposes. This change in land use has emerged due to the higher and consistent returns farmers receive for the same piece of land, which would have been under agriculture.

- Lack of entrepreneurial spirit in the youth shows a discouraging trend in adopting agriculture and allied activities as a source of income. Even though more than half of the country's population is employed in agriculture and allied activities, most of the rural youth are not attracted to a sector that is prone to low or no profitability due to production vulnerabilities, increased unpredictability in the natural environment due to climate change, lack of infrastructure support both physical and social, etc. Recently, the 


\section{International Journal of Social Science and Economic Research}

ISSN: $2455-8834$

Volume:05, Issue:10 "October 2020"

government's aim to double farmers' income by adopting the Integrated Farming System shows potential for retaining the youth and increasing agricultural income if the schemes and programmes are rightly implemented.

- Considering that adoption of technology, whether it is high yielding variety of seeds, irrigation systems or newer methods of cropping have been very slow to be adopted in this sector. As it is seen as a loss-making sector, agriculture often gets poor quality supply in the form of free power (Gambhir and Dixit 2018). Inducements like subsidies, tax exemptions have been poorly deployed, reaching fewer farmers than anticipated, and creating more economic and regional disparities.

- Dramatic rise in production of food grains with the Green Revolution in India brought in a series of social and ecological damage, and ultimately economic damage to the very farmers who adopted them. The intensive technologies adopted during the Green Revolution did not foresee the harmful impacts on the natural environment. The unsustainable consumption of high yielding variety (HYV) of seeds that require intensive irrigation and large scale use of fertilizers, pesticides and insecticides were highly polluting and toxic causing severe damage over the decades (T. Krishnakumar 2019 and Pepper 2008). Increasing regional disparities, indebtedness, farmer suicides, depleting ground water sources and toxicity of the soil have become apparent over the years (Bowender 1979, Zwerdling 2009 and Eliazer Nelson et al. 2019). There is a conscious need to put the natural environment as the core objective while considering adoption of new technologies.

Measures to double farmers income by 2022 have been taken up by the government seriously.Integrated Farming System (IFS) has become a common strategy adopted by most states to improve the socio-economic status and maintain the ecological balance. Although the concept has been around for sometime, it received popularity as an important component of doubling farmer's income by 2022 after Prime Minister Modi mentioned it while addressing a farmers' rally in Bareilly, Uttar Pradesh (The Hindu 2016).The IFS approach is helpful for farmers in India to supplement their incomes as a vast majority own small or marginal land holdings and some are even tenants or share croppers.

IFS combines cultivation of multiple crops (grains, pulses, vegetables and herbs) and running allied enterprises (animal farming, apiculture, fishery,mushroom cultivation)in an expanded symbiotic and synergistic system, where the waste of one process becomes input for the other process (Kumar et al. 2018). From modernising farming by promoting food processing units in the production catchment areas, increasing mechanisation like food harvesters, to adopting farming system models which include horticulture and animal husbandry, dairy, fisheries, government initiatives have helped farmers to generate steady income and employment. While 


\section{International Journal of Social Science and Economic Research}

ISSN: $2455-8834$

Volume:05, Issue:10 "October 2020"

IFS is gaining popularity in India, to make it a truly integrated and intelligent management system, it must use the available natural resources sustainably with an aim to alleviate risks.

The constraints and problems that the agriculture sector experiences are also opportunities to develop solutions. The idea of Atmanirbharta has been part of India's ethos since our freedom struggle. While transforming itself as an Atmanirbhar Bharat, India must bear in its core objective the need to balance the ongoing ecological. Sustainable development has to be the mantra if the agriculture sector aims to double farmers income with no negative impacts in the socio-economic life and natural environment of the farmers.Agriculture is directly influenced by the global ecological system and must therefore aim at being sustainable in the long run in order to make our farmers truly Atmanirbhar.

For transformation and modernization of agriculture in India, there is an urgent need to adopt newer technologies to keep up with the changing global environment. Like the fast growth of manufacturing and service sector, agriculture cannot be left behind.Adoption of a variety of solar technologies, is a strategy that will help all farmers, irrespective of their ownership of land or type of agricultural and farming practice. Effective means to help them can include providing the rural and agricultural population with solar lamps/lanterns, mini solar panels (to light up and run their small appliances), solar fencing and solar pumps to irrigate and manage water use and secure their cultivated crops without negatively affecting the socio-economic and ecological milieu.

\section{SOLAR TECHNOLOGIES}

Solar technologies that are developing vigorously - along with other renewable energy technologies (RET) - are a vital component to help farmers, irrespective of their ownership of land or tenancy. Solar technologies in many ways can help increase energy access through offgrid systems, and enhance energy security, cut input costs and make farmers self-reliant in more ways than one. As India is entering a phase of energy transition, it provides the agriculture sector with a window of opportunity to help farmers generate renewable power out of micro systems for consumption at home or in the field for lighting, charging appliances, irrigation, etc.

The improvement in the standard of living with the adoption of solar technologies cannot be quantified in a short time period; but the ones who experience the advantages of brighter and cleaner lighting, cooking fuel, cheaper and uninterrupted power supply can feel it immediately. Some of the primary advantages of solar power adoption are as follows:

- Solar power consumers enjoy better energy security as they minimise their cost of electricity for a period of 25 years, thereby hedging against variations in grid electricity prices that are tied to fossil fuel costs (Karan 2019). 


\section{International Journal of Social Science and Economic Research}

ISSN: $2455-8834$

Volume:05, Issue:10 "October 2020"

- The flexibility with solar energy is its scalability, it can be easily installed anywhere as a small off-grid power generating system, mounted on top of a rooftop or anywhere on the ground within the homestead, or as a solar streetlight, and as long as it receives direct sunlight for efficient generation of power.

- Solar energy systems are known for their simplicity in operation once they have been installed. Solar energy systems usually require little to no technical skill for operation and even an illiterate person can run these technologies with a hands on training or demonstration.

With the burgeoning demand for power - due to the high economic growth that Indian economy witnessed in the past few years - energy access and security have become a necessity. Knowing that conventional carbon-based fuels will not be able to cater to the power demand in the long run, alternative renewable energy sources like solar and will have to contribute significantly to the energy basket.

The rural and agricultural population have an excellent opportunity to skip the heavy dependence on fossil fuel-based supply of energy and switch to alternative sources like solar and wind. Yenneti (2012: 282) and Nouni et al .(2006) analysed that renewables have the maximum potential to power India's rural areas, which are presently highly dependent on fossil fuels.

Solar energy, by virtue of being ubiquitous and unlimited supply, has become a favourite frontrunner as a clean energy fuel in many countries globally. India is a tropical country receiving more than 300 days of sunshine with a potential of 5000 trillion KWh per year. India's transition to a clean energy economy in the decades to come, will help it achieve energy security and access for all but will also make it an exemplary leader in combating energy poverty, reduce indoor air pollution, create cleaner ambient air in cities, global warming and climate change.

\subsection{Adoption of Solar: A Herculean task}

Although solar has been part of India's mainstream national and foreign policy for more than a decade, solar technologies have not been as popular with the masses as anticipated. The central government has adopted a multipronged approach by rolling out multiple initiatives, policies and programmes to accelerate the growth of solar by holistically driving investments, resolving industry and stakeholders issues proactively, addressing policy concerns, all the while generating green jobs for the youth and skilling them with the progressive technologies (MNRE 2019). However, most states agree that solar infrastructure is not affordable for a majority of the population even with the subsidies that are prevailing. For instance, Haryana recommended the need for independent solar and water grids for agriculture to ensure availability and sustainability with government assistance (ICAR 2019). Some of the main challenges in its adoption are: 


\section{International Journal of Social Science and Economic Research}

ISSN: $2455-8834$

Volume:05, Issue:10 "October 2020"

Intermittency: It is an intermittent source of energy, which makes it capable of functioning well only during the day if there is no storage option for the excess power generated. The variable flow of power due to the changes in solar irradiance and temperature can affect the supply quality of a solar energy system as well.

Cost: High capital cost of installing power plants is also a deterrent but once installed the cost of maintenance and operation is much lower than that of fossil fuels.

Storage: Most off-grid systems cannot transfer the excess power the panels generate, as a result of which the surplus energy is wasted if not consumed. Smaller farmers cannot afford storage system as batteries are expensive and require technical knowledge for their upkeep and functioning.

Education and awareness: PV systems, although new and hitherto unknown, are making in roads into the agriculture sector. There is a lack of awareness and information dissemination by the government about the durability, feasibility and value of solar technologies in the agriculture sector.

Absence of lead agency: Multiple agencies deal with renewable energy. While the MNRE plans, implements supports and incentives, the Department of Science and Technology (DST) is in charge of $R \& D$, and the Ministry of Power (MoP) has the responsibility of dealing with power distribution. This multiplicity of agencies is a major deterrent to large scale adoption. SECI which has been made the nodal agency for all things related to solar energy was already under staffed and ill-equipped. It has recently been made responsible for all renewable energy sources making it more arduous on an already burdened institution.

Policy uncertainties: Policies of the government with respect to renewable energy has been highly uncertain. Its policies regarding import of PV panel components, net metering or power selling by solar rooftops or ground mounted systems need to be made more robust as it can be a means of additional income to farmers who will be motivated to adopt solar with their agricultural lifestyle.

Limited reach: The majority of benefits go to the public sector, especially in the urban area. The skewed incentive structures like the Solar Rooftop grid connected have been narrowed down to government building and large industries and institutions. The subsidies and incentives for offgrid systems, which can improve rural life have been much lesser with even lower intervention for information dissemination.

There are barrier in adoption of solar energy due to the problems related to land acquisition in rural areas, issues of funding projects has become a major roadblock especially in the Rooftop 


\section{International Journal of Social Science and Economic Research}

ISSN: $2455-8834$

Volume:05, Issue:10 "October 2020"

Solar PV scheme due to the apprehensions on returns. For instance, Chandrasekaran (2020) states that companies are seeking termination of Power Purchase Agreements due to:

- Delay in allocation of land for the project

- Delay in commissioning of transmission system

- Delay in adoption of tariff by SECI

- $\quad$ Outbreak of Covid-19

While some of these obstacles have existed since the inception of the JNNSM. However, administrative hurdles must be first rectified if India must effectively tackle climate changerelated food and energy shortages.

\subsection{Potential for solar energy technologies in agriculture and allied activities}

Solar technology presents multiple ways to reduce cost, generate alternative income and improve the quality of life of the rural agricultural areas. They can significantly contribute towards a sustainable, resilient and self-reliant rural agricultural community by enabling energy access and security of supply through off-grid PV systems. Agriculture in India has traditionally been a major consumer of electricity, accounting for an average of one-third of total power consumption in the national economy.

The need to increase investment in agricultural infrastructure such as irrigation facilities, warehousing, cold chain and storage has existed for awhile. Solar energy technologies that are emerging in the market can be of great value to the agriculture and allied sectors in India. It can be utilised in different phases and activities in agriculture - from sowing to post-harvesting, storage, food processing and even protection of farmlands. Although the cost of investment in solar PV is high, as mentioned earlier the cost of operation and maintenance is negligible with almost zero cost of generation over its life cycle. According to the SDG National Indicator Framework Progress Report 2020, the amount of fossil fuel subsidy per unit of GDP has decreased from 0.22 in 2015 to 0.19 in 2019-2020 (2019:33), this will continue to fall further as part of India's aim to ensure sustainable consumption and production patterns under SDG 12. Gambhir and Dixit's (2018) study shows that two-thirds of the total area under irrigation in India uses groundwater powered by 2 crore electric and 75 lakh diesel pumps. Solar pumps, which have been received very well by many states for deployment can reduce dependence on fossil fuel-based electricity supply, and create day-time, uninterrupted clean power supply, thereby increasing energy independence and discouraging unregulated pumping of water for irrigation.

Solar fencing to protect the fields from the invasion of animals have gained traction in the past few years but are still considered an expensive and less-known and tested alternative since not all states provide subsidy for such investments. Crop damage and loss of livestock and livelihood 


\section{International Journal of Social Science and Economic Research}

ISSN: $2455-8834$

Volume:05, Issue:10 "October 2020"

due to straying and preying of animals has been estimated to cost about INR 229 crores as per the Department of Agriculture, Government of India( Ministry of Agriculture and Farmers Welfare 2019). Itis a major cause of concern for many farmers, rural and forest dwellers. Alternatives like growing thorny bushes, manually guarding the fields, even planting explosives are seen to be unsustainable from a socio-economic and ecological perspective. Solar fences give a live but non-lethal shock to the intruder who encounters strands of plain wire (Reddy 2017). The alarm system in the solar fence alerts the owners and animals and thereby harming neither of the two.

Solar technology in the form of solar heaters and solar dryers are cost-effective ways of increasing livelihoods as they provide cleaner and cheaper alternatives to preserve their produce like turmeric, ginger, tobacco, dry fish and meats. In Andhra Pradesh, the government plans to use solar dryers and heaters to cure tobacco to reduce the dependency on traditional fuels like firewood, which is polluting and more tedious to collect. They intend to use solar dryer technology to dry fish, which reduces the time taken by $60-70 \%$ and the wastage by $20 \%$ (ICAR 2019: 10).

In the State Specific Strategies for Doubling Farmers Income - 2022, a comprehensive document prepared by the Indian Council of Agricultural Research, a compilation of the strategies and action plans of most states shows that there is scarce mention of renewable technologies for increasing farmer incomes. For instance, the strategy plan by the Uttar Pradesh government does mention the need for location-specific need-based technologies for raising agricultural production (2019: 623). These location-specific technologies, which require power, will be best catered by off-grid renewable energy sources, specifically solar, as these micro power houses will create access and a sense of secure accessibility. This will reduce reliance on the state utilities, prevent power disruptions, and reduce power costs. Rajasthan's action plan is to create agro-voltaic farming or solar farming to enhance the livelihood of farmers. Table 2 depicts the variation in the solar potential of states (in Gigawatt peak) in India visa-vis the percentage of land under irrigation. Rajasthan has the highest solar potential of $142.31 \mathrm{GWp}^{2}$ (gigawatt peak) in the country. With about 41 percent of the land under irrigation, solar technologies like solar pumps, fencing, solar collectors for drying and heating can be of immense help to farmers in the state. The same holds true for like Jammu and Kashmir Union Territory (111 GWp), Madhya Pradesh (61.66GWp with $43 \%$ land under irrgation), Maharashtra (64.32 GWp and 18.03\% land under irrigation), Gujarat (47.08 GWp and $47 \%$ under irrigation). Punjab has $98.72 \%$ of its land under irrigation but solar potential is about $2 \mathrm{GWp}$. This implies that irrigation relies on power distributed by utilities, which makes it a strong contender to adopt solar pumps to reduce power

\footnotetext{
${ }^{22}$ Gigawatt peak is the unit of measurement which tells how much power a standard Photovoltaic panel can deliver under optimal conditions.
} 
International Journal of Social Science and Economic Research

ISSN: 2455-8834

Volume:05, Issue:10 "October 2020"

cost and efficient use of power and ground water in the state to transform the rural and agricultural life of the people.

TABLE 2. Potential of Solar power and area Percentage of area under irrigation

\begin{tabular}{|l|l|l|l|}
\hline Sl. No. & State/UT & $\begin{array}{l}\text { Solar } \\
\text { Potential } \\
\text { (GWp) }\end{array}$ & $\begin{array}{l}\text { Area } \\
\text { Under } \\
\text { Irrigation } \\
\text { (in \%) }\end{array}$ \\
\hline 1 & Andhra Pradesh & 38.44 & 50.5 \\
\hline 2 & Arunachal Pradesh & 8.65 & 18.72 \\
\hline 3 & Assam & 13.76 & 9.16 \\
\hline 4 & Bihar & 11.2 & 68.65 \\
\hline 5 & Chattisgarh & 18.27 & 31.2 \\
\hline 6 & Delhi & 2.05 & 82.14 \\
\hline 7 & Goa & 0.88 & 24.6 \\
\hline 8 & Gujarat & 35.77 & 47.08 \\
\hline 9 & Haryana & 4.56 & 89 \\
\hline 10 & Himachal Pradesh & 33.84 & 21 \\
\hline 11 & J\&K & 111.05 & 42.83 \\
\hline 12 & Jharkhand & 18.18 & 14.25 \\
\hline 13 & Karnataka & 24.7 & 34.18 \\
\hline 14 & Kerala & 6.11 & 17.89 \\
\hline 15 & Madhya Pradesh & 61.66 & 43.26 \\
\hline 16 & Maharashtra & 64.32 & 18.23 \\
\hline 17 & Manipur & 10.63 & 18.03 \\
\hline 18 & Meghalaya & 5.86 & 37.13 \\
\hline 19 & Mizoram & 9.09 & 14.5 \\
\hline 20 & Nagaland & 7.29 & 21.2 \\
\hline 21 & Odisha & 25.78 & 28.69 \\
\hline 22 & Punjab & 2.81 & 98.72 \\
\hline 23 & Rajasthan & 142.31 & 41.96 \\
\hline 24 & Sikkim & 4.94 & 8.86 \\
\hline 25 & Tamil Nadu & 56.62 \\
\hline 26 & Telangana & 23.95 \\
\hline 27 & Tripura & NA \\
\hline
\end{tabular}


International Journal of Social Science and Economic Research

ISSN: $2455-8834$

Volume:05, Issue:10 "October 2020"

\begin{tabular}{|l|l|l|l|}
\hline 28 & Uttar Pradesh & 22.83 & 80.18 \\
\hline 29 & Uttarkhand & 16.8 & 49.45 \\
\hline 30 & West Bengal & 6.26 & 58.82 \\
\hline
\end{tabular}

Source: https://farmer.gov.in/irrigation.aspx\# and MNRE Annual Report 2019-2020.

\section{FIG.1. Solar Potential and Percentage of Area under Irrigation of Different States.}

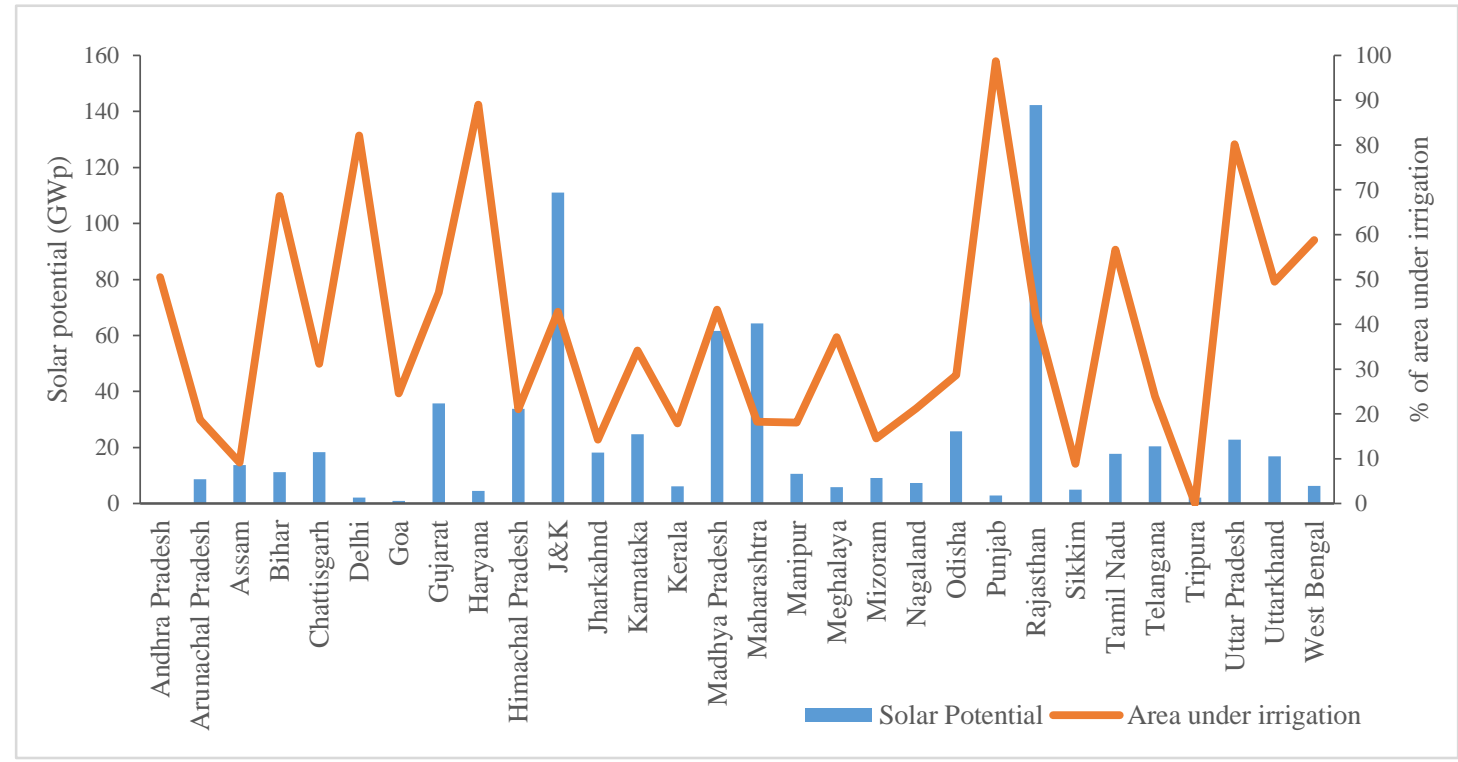

In Figure 1, the land under irrigation of various states is depicted with a curve while the solar potential is shown by the bars. The potential to harness solar energy in a few states for agricultural facilities is extremely high for states like J\&K, Rajasthan, Maharashtra and Madhya Pradesh. Uttar Pradesh ,Gujarat, Haryana, Punjab which have a high area under irrigation can also do very well in reducing power costs and subsidies if they use solar pumps for irrigation. Government schemes like PM-KUSUM (Pradhan Mantri Kisan Urja Suraksha evam Uthhan Mahabhiyan Yojana), CPSU (Government Producers) Scheme, Phase II of Solar Roof top, and Off-grid and Decentralised Solar PV Scheme, must be completed on time if we have to achieve the target of $100 \mathrm{GW}$ of solar energy production by 2022 . The government recently expanded this target to $450 \mathrm{GW}$ by 2030 . A total of INR 34,422 crores of central financial assistance has been provided for PM- KUSUM - the most recent Flagship programme for agriculture, related to solar energy. According to the MNRE, the scheme consists of three components:

1. Component-A: Setting up of 10,000 MW of Decentralized Grid Connected Solar or other Renewable Energy Power Plants on barren/fallow land; 
2. Component-B: Installation of 17.50 Lakh stand-alone solar agriculture pumps;

3. Component-C: Solarisation of 10 Lakh Grid Connected Agriculture Pumps.

FIG. 2. Cumulative Solar Street Lights, Solar Pumps and Solar Lamps Installed in India (2013-14 to 2019-20)

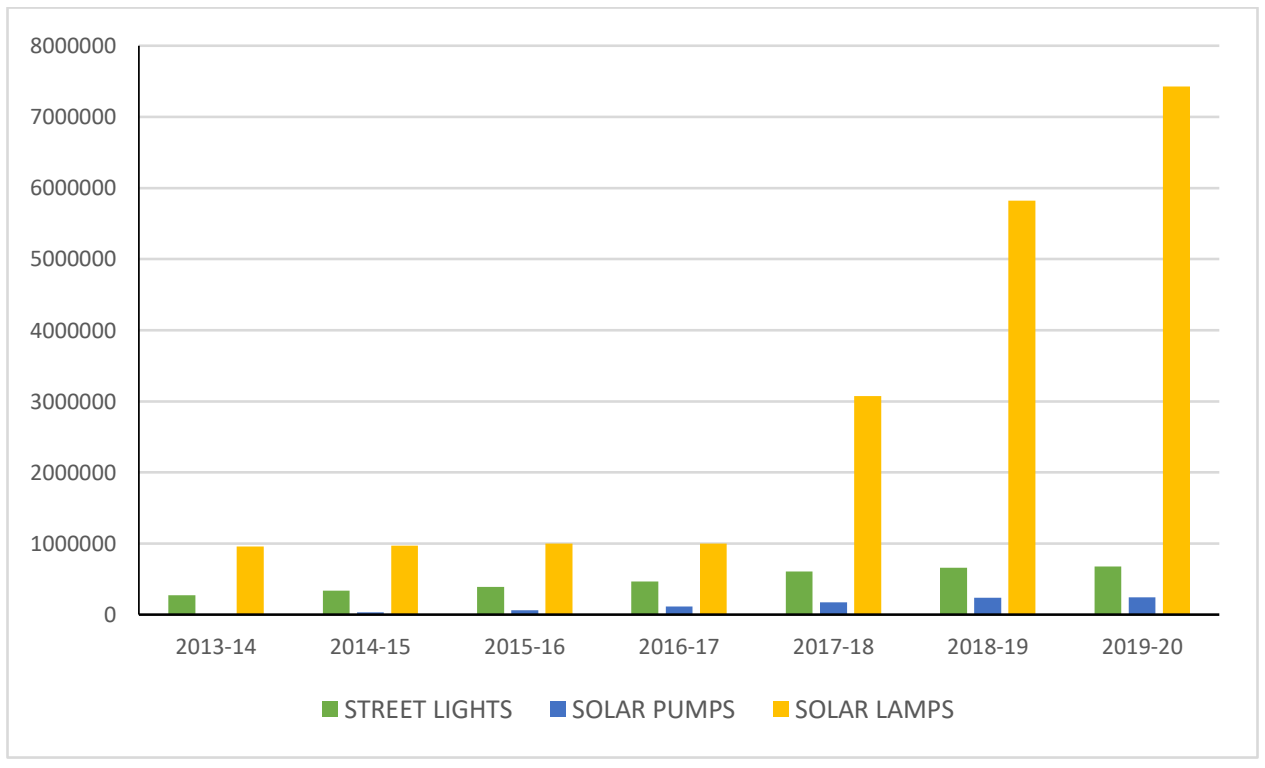

Off-grid and decentralised solar PV application programmes can have a multiplier effect with positive impacts in rural and agricultural settings. A cluster of villages, which rely on such off grid system over the long run, can become self-sustaining and resilient to climate change to a large extent. Grid-connected solar power plants and parks adjacent to rural areas must also distribute power to such settlements to reduce transmission and distribution losses that they would have incurred if they were to transmit and distribute the same to the urban areas that are located further. The aggregate technical and commercial losses incurred by distribution companies was about $25.41 \%$ ( Chakraborty and Kaur 2018). This will also help the rural and farming community to get clean energy access to run solar pumps, fences and storage units, etc. Gambhir and Dixit (2018) suggest that the availability of the electricity grid in every village, coupled with the national feeder separation programme will make this cost-effective and rapidly scalable approach imminently feasible across thenation. Thus, it will create a win-win-win approach for farmers, the government and debt-ridden distribution companies (DISCOMS).

The ICTs' infrastructure that the government provides for farmers and rural population for increasing awareness of government schemes, policies, weather forecasts and updates requires power to run kiosks, televisions, computers, mobile phone towers, mobile phones, radios etc. Solar panels provide an easy, cheap and reliable option for powering them with clean and 


\section{International Journal of Social Science and Economic Research}

ISSN: $2455-8834$

Volume:05, Issue:10 "October 2020"

uninterrupted power supply, especially in remote and inaccessible areas. This will in turn enhance their incomes, socio-economic environments and quality of life.

\subsection{Diffusion of Solar Technologies in India}

Solar technology presents multiple ways to reduce cost, generate alternative income and improve the quality of life of farmers due to easy management and operability, with low maintenance cost. Solar PV systems are a relatively new and unfamiliar technology for most farmers and rural population. There is a sincere need to reduce the time for innovative technology transfer and capacity-building in agriculture and rural areas .The complex socio-economic-environmental challenge in India makes innovative renewable energy technologies difficult to be adopted. Dark et al. (2014: 199) states that innovations like renewable energy technologies rarely find readymade markets, and it is often necessary to create one to stimulate demand. This is where the government intervention in information dissemination, stimulation of demand through financial support, and the creation of avenues and markets to supply such technologies becomes necessary. The mandates of the government specifying concrete actions have been laid down but lack of implementation has made the diffusion of solar technology slow in India.

With a large proportion of youthful population moving away from the agriculture sector, there is a need to transform and refocus on agriculture and allied activities as a highly remunerative venture, providing income from multiple sources. This is possible if a modern, integrated and systematic farming system is adopted. Agriculture, for the longest time, lacked sustainable technological intervention and has suffered tremendously because of this lacunae. Introducing new technologies, even if they are the best, is never an easy task, especially if the substitutes are expensive, alien to the people, and not backed by incentives or inducements. In India, where agriculture is linked to tradition and culture, adoption of innovative technologies is very challenging. Rogers (1962) and Dark et.al (2014) agree that apart from political and economic factors, social factors and the process of socialisation impacts how technologies are adopted and diffused over time. The state, as an agent of society, must focus on the youthful population, as they are the agents of change, risk-takers, and early adopters of innovation. They are more receptive tothe adoption of newer ideas to improve their livelihoods. The rising urban and rural population is going to create a robust demand and huge potential of growth. India's agriculture will have to be resilient to keep pace with the need to maintain food security and greater opportunities for export in the long run.

\section{CONCLUSION}

With climate conditions globally becoming more erratic, more area under agriculture will be affected, more land will need to be irrigated, and technologies will be necessary to maintain food security. Energy-saving technologies will have to be the way forward for India's agricultural 


\section{International Journal of Social Science and Economic Research}

ISSN: $2455-8834$

Volume:05, Issue:10 "October 2020"

sector to be resilient and self-reliant in an ever-increasingly unpredictable global environment. Solar pumps, solar lanterns, solar street lighting and off grid PV systems in the rural and agricultural areas will help in efficient use of water and electricity, enhance cropping intensity and productivity as agriculture will rely less on power distributed by utilities, especially if subsidies in electricity for agriculture are phased out.

With the recent announcement and implementation of the PM-KUSUM scheme that focuses on solar technologies and infrastructure development, there is hope for agriculture and rural India. There is a need for widespread adoption and diffusion of solar rooftop and solar panel ground mounted off grid systems on a cluster basis to help power KVKs, ICT centres, seed centres, and kiosks for ATMs, weather forecasts to further disseminate the positive impacts of solar technologies for building resilient and sustainable agriculture. Such schemes will further create green jobs for the rural youth who can gain technological skills to handle these systems. Therefore, solar energy and related innovative technologies will help Indian agriculture transform from a stagnating and unpromising sector to a climate change-resilient, high growth and revenue-generating sector for a truly Atmanirbhar Bharat.

\section{REFERENCES}

Bowonder, B. (1979), "Impact analysis of the green revolution in India", Technological Forecasting and Social Change, 1(4) December 1979, 297- 313.

Central Electricity Authority (CEA) (2020), Ministry of Power, Monthly Report of All India Installed Capacity of Power Plants.

https://cea.nic.in/monthlyinstalledcapacity. html.

Chakraborty, Lekha and Kaur, Amandeep (2018), "Are DISCOMS unsustainable? UDAY Portal Data shows the average AT\&C Losses at 25.41\%", Financial Express, $16^{\text {th }}$ November 2018. https://www.financialexpress.com/opinion/are-discoms-unsustainable-uday-portal-data-showsthe-average-atc-losses-at-25-41/1383184/.

Chandrasekaran, K (2020), "Renew Power, Mytrah Energy, Torrent Power seek termination of PPAs",Economic Times, 22 ${ }^{\text {nd }}$ September 2020.

https://energy. economictimes.indiatimes.com/news/renewable/renew-power-mytrah-energytorrent-power-seek-termination-of-wind-power-ppas/78248641.

Dark, M., Daugherty,J., Cambell, P. and Grimson, William (2014), "Taking Emerging Renewable Technologies to Market", in Eugene D. Coyle (eds), Understanding the Global Energy Crisis Book, 193-209,Indiana: Purdue University Press. 


\section{International Journal of Social Science and Economic Research}

ISSN: $2455-8834$

Volume:05, Issue:10 "October 2020"

Eliazer Nelson et al. (2019)," The Impact of the Green Revolution on indigenous crops of India", Journal of Ethnic Foods, (2019) 6:8 ttps://doi.org/10.1186/s42779-019-0011-9

Everett M. Rogers (1962),Diffusion of Innovations, New York: Free Press

Kumar, S., Bhatt B P, Dey A, Shivani, Kumar, U., Idris MD, Mishra J S and Kumar S(2018), “ Integrated Farming System in India: Current Status, Scope and Future Porspects in Changing Agricultural Scenario", Indian Journal of Agricultural Science, 88(11): 1661-75.

Gambhir, Ashwin and Dixit, Shantanu (2018), "Powering agriculture via solar feeders", The Hindu Business Line, 20th December 2018.

https://www.thehindubusinessline.com/opinion/powering-agriculture-via-solar feeders/article25791629.ece.

Government of India, Ministry of New of Renewable Energy, Jawaharlal Nehru National Solar Mission: Mission Document, 18theNovember 2008, https://www.seci.co.in/upload/static/files/mission_document_JNNSM(1).pdf.

Government of India, Ministry of Statistics and Programme Implementation (MoSPI), (2017a) Gross Area under Irrigation, http://www.mospi.gov.in/publication/compendium-selected-indicators-indian-economy-specialissue-time-series-data-volume-i.

Government of India,Ministry of Statistics and Programme Implementation (MosPI), (2017b) Net Area Under Irrigation by Source, All India.

http://mospi.nic.in/statistical-year-book-india/2017/181.

Government of India, Ministry of New and Renewable Energy, (2019),Annual Report 20192020, New Delhi.

https://mnre.gov.in/img/documents/uploads/file_f-1597797108502.pdf.

Government of India, Ministry of Agriculture and Farmers Welfare (2019), Annual Report 20182019, New Delhi.

http://agricoop.nic.in/sites/default/files/AR_2018-19_Final_for_Print.pdf.

Government of India, National Statistical Office (2019), Sustainable Development Goals Nation Indicator Framework: Progress Report, 2020, New Delhi.

http://mospi.nic.in/sites/default/files/publication_reports/Sustainable_Development_Goals_Natio nal_Indicator_Framework_Progress_Report_2020_Version2.1.pdf. 


\section{International Journal of Social Science and Economic Research}

ISSN: $2455-8834$

Volume:05, Issue:10 "October 2020"

Nouni, M. R., Mullick, S C. and Kandpal, T.C (2006), "Photovoltaic projects for decentralised power supply in India: A Financial Evaluation, Energy Policy, 34(18): 3727-3738, https://doi.org/10.1016/j.enpol.2005.08.015

Indian Council of Agricultural Research (2019), State Specific Strategies for Doubling Farmers Income- 2022,

https://icar.org.in/sites/default/files/Doubling-of-Farmers-Income-02.pdf.

Karan, Manu (2019), "How India in a short period of time has become the cheapest producer of solar power", Economic Times, July 22 2019,

https://economictimes.indiatimes.com/small-biz/productline/power-generation/how-india-in-a-

short-period-of-time-has-become-the-cheapest-producer-of-solar-

power/articleshow/70325301.cms?from $=$ mdr.

Pepper, Daniel (2008), “The Toxic Consequences of the Green Revolution”, USNews, July 7, 2008 ,

https://www.usnews.com/news/world/articles/2008/07/07/the-toxic-consequences-of-the-greenrevolution.

Reddy, Santosh (2017), "Solar fencing helping Indian Farmers”, MyStory, 29th Aug 2017, https://yourstory.com/mystory/b09c3f7ef7-solar-fencing-helping.

The Hindu (2016), "My Dream is to See Farmers Double Their Income by 2022: PM" Feb 28 2016 ,

https://www.thehindu.com/news/national/prime-minister-narendra-modi-addresses-kissan-rallyin-bareilly-uttar-pradesh/article8292286.ece.

T, Krishnakumar (2019), “ Agrarian Crisis \& Food Security in India”, 22 January 2019, DOI:10.13140/RG.2.2.26406.57925.

https://www.researchgate.net/publication/330533632_AGRARIAN_CRISIS_FOOD_SECURIT Y_IN_INDIA.

Yenneti, Komalirani, (2012), “ The Sun Shines on India- A Review of the Implementation and Fiancial Continuum of the National Solar Mission", Renewable Energy Law and Policy Review, 2012 Vol3 (4): 280-291.

Zwerdling, Daniel (2009), “'Green Revolution' Trapping India's Farmers in Debt”, NPR, $14^{\text {th }}$ April 2009,

https://www.npr.org/2009/04/14/102944731/green-revolution-trapping-indias-farmers-in-debt. 